\title{
Differential roles of p63 isoforms in epidermal development: selective genetic complementation in p63 null mice
}

\author{
E Candi ${ }^{1}$, A Rufini ${ }^{1}$, A Terrinoni ${ }^{1}$, D Dinsdale ${ }^{2}$, M Ranalli $^{1}$, \\ A Paradisi ${ }^{1}$, V De Laurenzi ${ }^{2}$, LG Spagnoli ${ }^{1}$, MV Catani ${ }^{1}$, \\ S Ramadan ${ }^{1}$, RA Knight ${ }^{2}$ and G Melino ${ }^{*, 1,2}$ \\ 1 Biochemistry Laboratory, IDI-IRCCS, c/o University of Rome 'Tor Vergata', \\ 00133 Rome, Italy \\ 2 Medical Research Council, Toxicology Unit, Leicester University, Leicester \\ LE1 9HN, UK \\ * Corresponding author: G Melino, Medical Research Council, Toxicology Unit, \\ Hodgkin Building, Leicester University, Lancaster Road, PO Box 138, Leicester \\ LE1 9HN, UK. Tel: + 44116252 5616; Fax: + 44116252 5551; \\ E-mail: gm89@le.ac.uk
}

Received 03.3.06; revised 08.3.06; accepted 08.3.06; published online 07.4.06 Edited by $\mathrm{P}$ Vandenabeele

\begin{abstract}
Epidermal development requires the transcription factor $\mathrm{p} 63$, as p63- $I-$ mice are born dead, without skin. The gene expresses two proteins, one with an amino-terminal transactivation domain (TAp63) and one without ( $\triangle \mathrm{Np} 63)$, although their relative contribution to epidermal development is unknown. To address this issue, we reintroduced TAp63 $\alpha$ and/or $\Delta \mathrm{Np} 63 \alpha$ under the $\mathrm{K} 5$ promoter into $\mathrm{p} 63-/-$ mice by in vivo genetic complementation. Whereas $\mathrm{p} 63-1-$ and p63-I-;TA mice showed extremely rare patches of poorly differentiated keratinocytes, $\mathrm{p} 63-I-; \Delta \mathrm{N}$ mice showed significant epidermal basal layer formation. Double TAp63 $\alpha$ l $\Delta N p 63 \alpha$ complementation showed greater patches of differentiated skin; at the ultrastructural level, there was clear reformation of a distinct basal membrane and hemidesmosomes. At the molecular level, $\Delta \mathrm{Np} 63$ regulated expression of genes characteristic of the basal layer (K14), interacting (by Chip, luc assay) with the third p53 consensus site. Conversely, TAp63 transcribed the upper layer's genes (Ets$1, \mathrm{~K} 1$, transglutaminases, involucrin). Therefore, the two p63 isoforms appear to play distinct cooperative roles in epidermal formation.

Cell Death and Differentiation (2006) 13, 1037-1047. doi:10.1038/sj.cdd.4401926; published online 7 April 2006
\end{abstract}

Keywords: p63; epidermis; cornification; skin; development

Abbreviations: TA, transactivation domain; $\Delta \mathrm{N}$, amino-terminal truncated protein; H\&E, haematoxylin and eosin; tg, transgenic mice; p63-/-; $\Delta \mathrm{N}$, mice knockout for p63, re-expressing $\Delta N p 63 \alpha$; p63-/-;TA, mice knockout for p63, re-expressing TAp63 $\alpha$; p63-/-; $\Delta \mathrm{N} ; \mathrm{TA}$, mice knockout for p63, re-expressing both $\Delta \mathrm{Np} 63 \alpha$ and TAp73 $\alpha$
The skin consists of two compartments, the dermis and the epidermis. The latter is a multilayered, stratified epithelium continuously regenerated by terminally differentiating keratinocytes, a process called cornification ${ }^{1-3}$ (Figure $1 a$ and b). Recent evidence demonstrates a major role for $\mathrm{p} 63,{ }^{4}$ a member of the p53 family, ${ }^{5-8}$ in this process as mutations in the TP63 gene cause limb and skin defects in humans, ${ }^{9}$ and p63-/- mice have no epidermis, no limbs and die at birth owing to dehydration. ${ }^{10,11}$

The expression of p63 proteins originates from two promoters, giving rise to TAp63 and $\Delta \mathrm{Np63}$ isoforms. In addition, both isoforms undergo alternative splicing at the C-terminus producing three different TAp63 and $\Delta$ Np63 isoforms $(\alpha, \beta$ and $\gamma)$. Although there is solid evidence that p63 is involved in epithelial development, ${ }^{10,11}$ for example, via regulation of PML, ${ }^{11-13}$ and in aging, ${ }^{13}$ the relative contribution of the different $\mathrm{N}$-terminal isoforms to epidermal formation has not been established. To address this issue, we have, therefore, generated transgenic mice expressing either TAp63 $\alpha$ or $\Delta \mathrm{Np} 63 \alpha$ under the control of the keratin (K) 5 promoter. The $\mathrm{K} 5$ promoter specifically drives the expression of the gene in the basal layer, the proliferative compartment of the epithelium. TAp63 $\alpha$ and $\Delta \mathrm{Np} 63 \alpha$ transgenic mice were used to generate isoform-specific complemented mice in the knockout background. The data presented are consistent with a role for $\Delta \mathrm{Np} 63 \alpha$ in controlling the expansion of epithelial cells from progenitor precursors in epidermal epithelia, to allow $\operatorname{TAp} 63 \alpha$, acting synergistically and/or subsequently to $\Delta \mathrm{Np} 63 \alpha$, to control epithelial differentiation.

\section{Results}

\section{Transgenic complemented mice}

To elucidate the individual role of the TAp63 $\alpha$ and $\Delta N p 63 \alpha$ isoforms in the development of the epidermis, we generated transgenic mice expressing either isoform under the control of the K5 promoter and then crossed these mice into a p63-/background (Figure 1c-f). Founder transgenics (four TAp63 $\alpha$ and five $\Delta \mathrm{Np} 63 \alpha$ ) were generated by microinjecting the purified transgene into the pronuclei of zygotes and then implanting the zygotes into pseudo-pregnant female mice. Lines were established and maintained by backcrossing the founders with C57/B6 mice. All founders were fertile and produced transgenic offspring at the expected Mendelian frequencies without any obvious abnormalities. We obtained two different mouse lines for each isoform, all of which showed similar levels of expression of TAp63 $\alpha$ or $\Delta \mathrm{Np} 63 \alpha$ proteins in the basal layer. The density of the hair follicles, and outer appearance of the skin and fur were normal. Efficient expression of the transgenes was evident both by immunostaining on skin biopsies and by Western analysis on cultured primary keratinocytes. Expression was restricted to the 

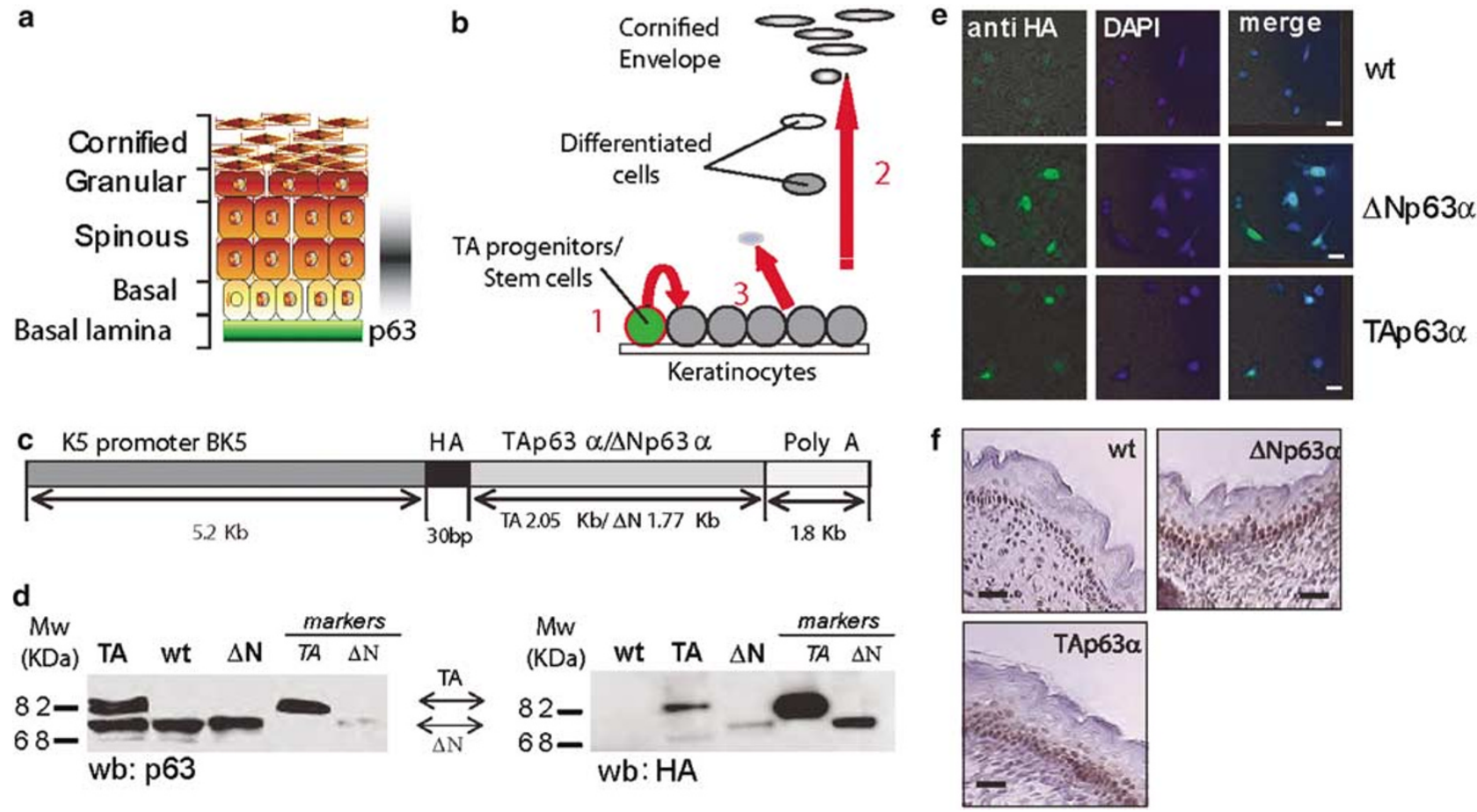

Figure 1 Expression of TAp63 $\alpha$ or $\Delta \mathrm{Np63} \alpha$ under the control of the $\mathrm{K} 5$ promoter in transgenic mice. We obtained two different mouse lines for each isoform, all of which showed similar levels of expression of TAp63 $\alpha$ or $\Delta$ Np63 $\alpha$ proteins in the basal layer. (a) $\Delta$ Np63 and TAp63 are both expressed in the basal layer, with $\Delta$ Np63 being predominant. (b) The role of the $p 63$ protein is still controversial, ${ }^{23,24}$ regulating either the stem cells/transient amplifying (TA) cells ${ }^{11}$ (1) or their differentiation ${ }^{10}(2)$ or cell death ${ }^{28}(3)$. The data herein reported are compatible with the first hypothesis, with distinct roles for $\triangle N p 63$ and TAp63. (c) The $5.2 \mathrm{~kb}$ K5 constructs used to express TAp63 $\alpha$ or $\Delta \mathrm{Np} 63 \alpha$ in basal keratinocytes. Mouse $\mathrm{cDNAs}$ are fused in-frame at the $\mathrm{N}$-terminal end with an HA epitope. The distances in $\mathrm{kb}$ are indicated in the figure. (d) Expression of the transgene in cultured primary keratinocytes. Western blots for p63 (left, showing endogenous and transgenes) or HA tag (right, showing only transgenes). TA and $\Delta \mathrm{N}$ indicate the protein expression in representative transgenic mice ( $\Delta \mathrm{Np} 63 \alpha$ or TAp63 $\alpha$ ). The two lanes on the right show a marker control for both TAp63 $\alpha$ and $\Delta$ Np63 $\alpha$ proteins. (e) Immunofluorescence for the transgene (stained using an antibody against the HA tag) shows a nuclear localisation for both the TAp63 $\alpha$ and $\Delta$ Np63 $\alpha$ proteins in primary keratinocytes cultured from the transgenic mice. Bar $=15 \mu \mathrm{m}$. (f) Immunohistochemistry of p63 in epidermis, using anti-HA antibody for transgenic mice and anti-p63 (Ab4 clone) for wt mice, showing overexpression of the transgene (brown colour) in the basal layer of the epidermis only. $\mathrm{Bar}=120 \mu \mathrm{m}$

epidermal basal layer and in tissues where $\mathrm{K} 5$ is normally expressed (thymus, eye, lung), but not in other tissues including bone, muscle, liver (not shown). Figure 1d shows the immunoblot staining with antibodies specific for p63 (left panel) and for the haemagglutin-antigen (HA) tag (right panel). The transgene was overexpressed as a nuclear protein, as shown in Figure 1e, in the basal layer of the epidermis, Figure 1f, consistent with the known specificity of the K5 promoter. To obtain double mutant mice, the transgenic mice overexpressing TAp63 $\alpha / \Delta \mathrm{Np} 63 \alpha$ were backcrossed with $\mathrm{p} 63+1-$ mice $^{11}$

The p63-/-;TA (mice knockout for p63, re-expressing TAp63 $\alpha$ ) and p63-/-; $\Delta \mathrm{N}$ (mice knockout for p63, re-expressing $\Delta \mathrm{Np} 63 \alpha$ ) transgenic mice died at birth, like the p63-/mice (Figure 2). TAp63 $\alpha$ complemented mice, like p63-/animals, had only very limited areas of epithelialisation with abnormal visibility of the vasculature through the skin (Figure 2d) due to the absence of the epidermis. In contrast, the p63-/ $-; \Delta \mathrm{N}$ transgenic mice showed greater, although still limited, macroscopical formation of the epidermis (Figure 2c). In agreement with this observation, the $\Delta \mathrm{Np} 63 \alpha$ complemented animals expressed greater amounts of the characteristic basal layer proteins, $\mathrm{K} 5$ and $\mathrm{K} 14$, than either the p63-/- or the p63-/-;TA mice (Figures 3a, b and 4a). No significant increase in the expression of upper layer markers (K1, loricrin) was detected in p63-/-;TA and p63-/-; $\Delta \mathrm{N}$ transgenic mice (Figure $3 c$, d and $4 b, c)$.

At the ultrastructural level, unlike wild-type (wt) mice (Figure 5a), these three groups (p63-/-, p63-/-;TA, p63 $-/-; \Delta N$ ) were all devoid of fully keratinised squamous corneocytes, intercellular lipid or corneodesmosomes, and there were no recognisable filaggrin granules or keratin fibrils (Figure 5b-d). No traces of hemidesmosomes/basement membrane were found in any of these animals. The surface layers of $\mathrm{KO}$ mice were dominated by fibroblast-like cells interspersed by irregular cell profiles that contained a few randomly arranged keratin filaments. These cells were not restricted to the outer surface but showed localised cornification of their cell envelopes and many contained some enlarged, osmiophilic granules (Figure $5 b$ ). The contents of these granules were extracted, from resin sections, and were identified as loricrin granules (not shown). TAp63 $\alpha$ complemented mice had only very limited areas of epithelialisation and the resulting cell profiles usually contained enlarged loricrin granules together with accumulations of a moderately electron-dense material, presumably filaggrin (Figure 5c). In contrast, the epidermis of the p63-/ $; \Delta \mathrm{N}$ mice contained many cells with traces of randomly dispersed keratin filaments and signs of nuclear disintegration or cornification of the cell envelope, but these cells were often overlaid by non-cornified 

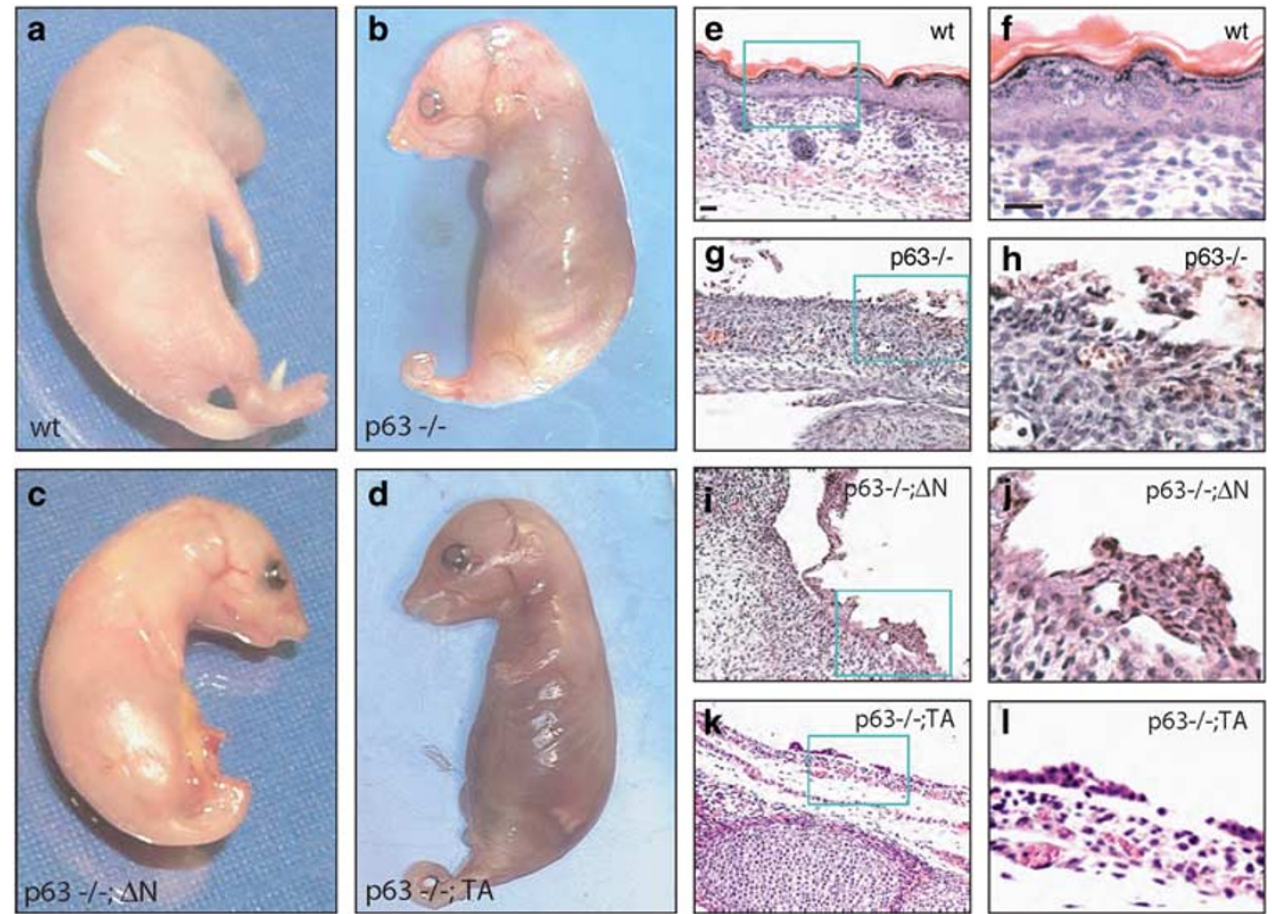

Figure 2 Reintroduction of TAp63 $\alpha$ or $\Delta \mathrm{Np63 \alpha}$ in p63-I- mice by genetic complementation. Morphology (a-d) and haematoxylin and eosin (H\&E) skin biopsy staining (e-l) of newborn mice. Bar $=250 \mu \mathrm{m}(\mathbf{e}, \mathbf{g}, \mathbf{i}, \mathbf{k})$ or $50 \mu \mathrm{m}(\mathbf{f}, \mathbf{h}, \mathbf{j}, \mathbf{l})$. (a, e, f) wt newborn mice. (b, $\mathbf{g}, \mathbf{h})$ p63-l-knockout mice. At a gross morphological level, there is no epidermis, allowing the clear visibility of the dermis. Limbs and skin annexes are also absent. Histologically, only few skin patches are present. (c, $\mathbf{i}, \mathbf{j})$ p63-Itransgenic mice with reintroduction of $\Delta \mathrm{Np} 63 \alpha$. There is some reformation of the epidermis, as shown by a detachable upper layer. (d, $\mathbf{k}, \mathbf{I}) \mathrm{p} 63-/-$ transgenic mice with reintroduction of TAp63 $\alpha$. There is no epidermis at a gross morphology level; histologically, the skin is similar to the p63 null mice

cells (Figure 5d). Many of the cornified cells contained accumulations of the moderately electron-dense material, seen in TAp63 $\alpha$ complemented mice. These data indicate that the effect of $T A p 63 \alpha$ in regenerating the epithelium, if reintroduced through the $\mathrm{K} 5$ promoter, is very limited, and that selective reintroduction of $\Delta \mathrm{Np} 63 \alpha$ can only partially restore the p63 null phenotype. We therefore formulated the hypothesis that a synergistic action of TAp63 $\alpha$ and $\Delta \mathrm{Np} 63 \alpha$ is necessary for the formation of the epidermis.

\section{Double-complemented mice}

Accordingly, we reintroduced both $\mathrm{TAp} 63 \alpha$ and $\Delta \mathrm{Np} 63 \alpha$ into the p63-/- background (Figure 6). The mice died within 12$18 \mathrm{~h}$ of birth and the gross phenotype reported for the p63-/mice was not fully reverted. However, there was a greater degree of re-epithelialisation than in the selective $\Delta \mathrm{Np} 63 \alpha$ genetic complementation, and much greater than in the p63-/ - and p63-/-;TA mice. These epidermal patches expressed $\mathrm{K} 5$ and $\mathrm{K} 14$ (Figure 6c), which normally characterise basal layers, together with $\mathrm{K} 1$ and loricrin (Figure $6 \mathrm{~d}$ ), which are usually associated with the upper layers. The skin patches in the p63-/-; $\Delta \mathrm{N} ; \mathrm{TA}$ (mice knockout for p63, re-expressing both $\Delta \mathrm{Np} 63 \alpha$ and TAp73 $\alpha$ ) mice had a greater degree of organisation and were more differentiated (Figure 7). Definite flattening and layering of the superficial cells was observed in many of these patches, but cornification was invariably incomplete and no corneodesmosomes or traces of intercellular lipid were found. Throughout the epidermis, keratin filaments were usually organised into fibrils and were associated with fibrillar granules in the more superficial layers (Figure 7). Underlying some of the skin patches were traces of a basement membrane together with numerous but indistinct hemidesmosomes (Figure 7d). The results indicate that reintroduction of $\mathrm{TAp} 63 \alpha$ and $\Delta \mathrm{Np} 63 \alpha$ not only expanded the number of keratinocytes and consequently expanded the expression of epidermal-specific proteins, but the proteins expressed (filaggrin, keratins, loricrin) are assembled correctly in the epidermis (i.e. filaggrin granules associated with keratin filaments). More importantly, in the double-complemented mice, we detected basal lamina and hemidesmosomes, structures that are crucial for the formation of a functional pluristratified epithelium and which are absent in the null mice. This is of particular interest as p63 has been recently demonstrated to be essential for the symmetry of cell division. ${ }^{14}$

\section{Biochemical evaluation of epidermal proteins}

In order to address whether the primitive epidermis in these animals had become detached mechanically in the birth canal, we isolated embryos at E19.5 and washed extensively for $24 \mathrm{~h}$ in a buffer ( $1 \%$ SDS and $20 \mathrm{mM}$ DTT) to solubilise the epidermal proteins; some degree of mechanical friction was also gently applied. This procedure may produce a more representative quantification of the epidermal proteins expressed in the different transgenic mice. K14, filaggrin and loricrin were expressed, although to a limited extent, in p63-/- mice (Figure 4a-c), demonstrating that their production can be regulated by genes other than p63. Reintroduction 


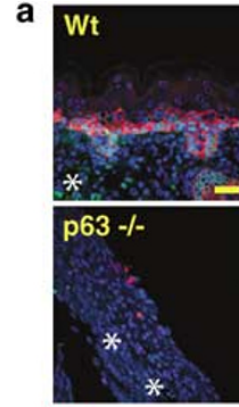

K14:p63:Dapi
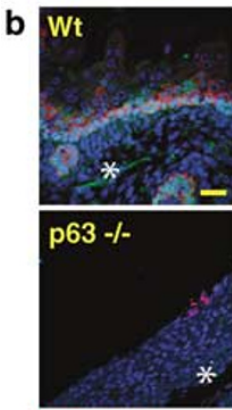

K5:p63:Dapi

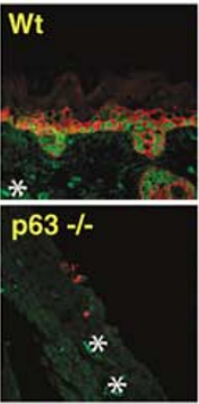

K14:p 63
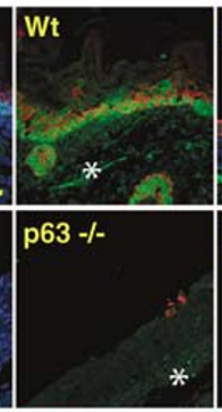

K5:p63
K14:p63:Dapi

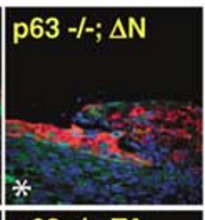

p63 - - TA

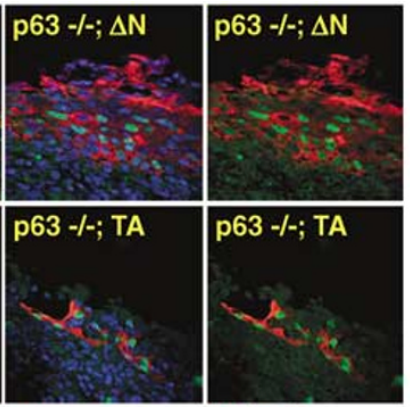

K14:p63
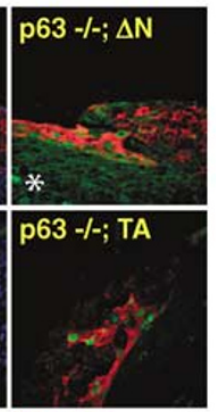

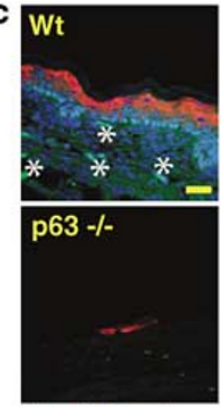

K1:p63:Dapi
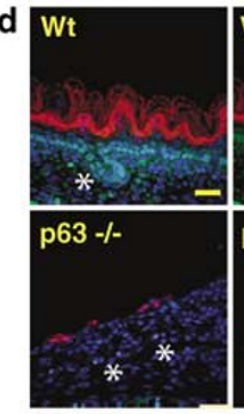

Lor:p63:Dapi

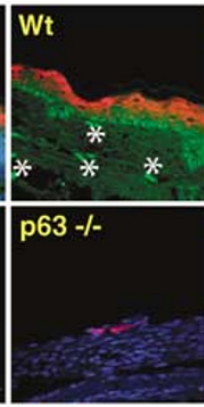

K1:p63
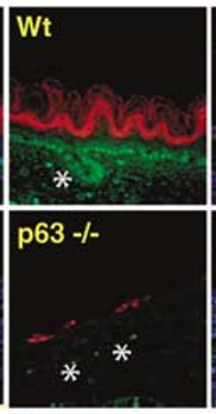

Lor:p63

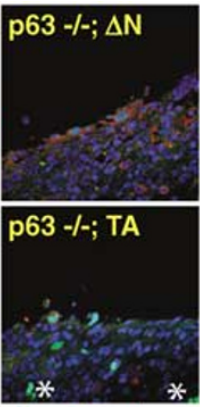

K1:p63:Dapi
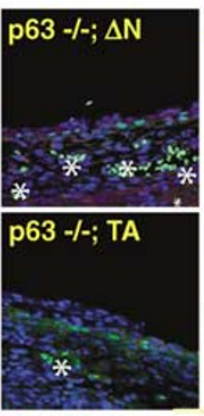

Lor:p63:Dapi

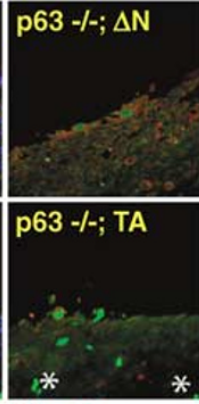

K1:p63

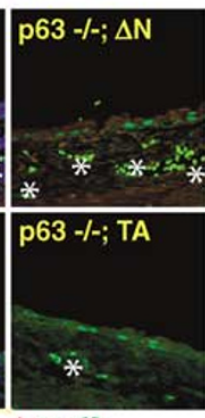

Lor:p63

Figure 3 Expression of epidermal differentiation proteins by confocal immunostaining in p63-/- mice before and after reintroduction of TAp63 $\alpha$ or $\Delta$ Np63 $\alpha$. Colour code and markers of the basal (K5, K14) layers are indicated. Bar $=50 \mu \mathrm{m}$. (a) Staining for K14, p63 and Dapi. K14 was visible in very rare patches of the epidermis in the p63-I- mice. The reintroduction of $\Delta$ Np63 $\alpha$ into the p63-I- background allows the reconstruction of the basal layer in several skin areas, with expression of K14. White stars indicate autofluorescent blood cells, also visible in unstained slides. (b) Staining for K5, p63 and Dapi. Like K14, K5 is also re-expressed in p63-/-; $\Delta \mathrm{N}$ transgenic mice. K5 (like K14) was already visible in very few sections of the p63-/- mice, as shown. White stars indicate autofluorescent blood cells, also visible in unstained slides. Skin biopsies were taken from newborn mice. (c, d) Colour code and markers of the upper (K1, loricrin) layers are indicated. (c) Staining for K1, p63 and Dapi. $\mathrm{K} 1$ is detected in very rare areas of p63-I-, p63-I-; $\Delta \mathrm{N}$, p63-I-;TA complemented mice. (d) Staining for loricrin, p63 and Dapi. Loricrin is detected in very rare areas of upper epidermal layers in p63-I-, p63-I-; $\mathrm{N}$, p63-I-;TA complemented mice. White stars indicate autofluorescence of blood cells. All bars $=50 \mu \mathrm{m}$

of TAp63 $\alpha$ did not significantly increase expression of these proteins. However, consistent with the previous data, selective complementation with $\Delta \mathrm{Np} 63 \alpha$ resulted in significantly enhanced expression of $\mathrm{K} 14$ and filaggrin, which was further enhanced in the double p63-/-; $\Delta \mathrm{N} ; \mathrm{TA}$ complemented mice. Loricrin in normal skin is stored in L-granules (see electron microscopy results) before being crosslinked by transglutaminases (TG) in the upper granular layer, and can be solubilised by SDS buffer and detected mainly as a monomer in Western blot (Figure 4c). In contrast, in the p63-/- and p63-I- complemented mice, which do not have proper granular layer formation, loricrin is not stored in the normal, small granules. In these animals, any loricrin in the abnormally large, osmiophilic granules may be sequestered from membrane-bound enzymes, but cytoplasmic loricrin is immediately crosslinked by TG. Indeed, the presence of crosslinked loricrin (Figure 4c) reflects the expression and enzymatic activation of TG in non-complemented p63-/- mice, which is enhanced after transgenic complementation.

\section{Molecular targets of the individual p63 isoforms}

As the in vivo evidence indicated that $\Delta \mathrm{Np} 63 \alpha$ facilitates the formation of the basal layer, we decided to investigate the underlying molecular mechanisms. As TP63 is a transcription factor, we performed a gene array analysis using Tet-On inducible cell lines expressing individual p63 isoforms. ${ }^{15}$
Several genes are regulated by $\operatorname{TAp} 63 \alpha$ and $\Delta \mathrm{Np} 63 \alpha$. A total of 171 genes are upregulated by TAp63 $\alpha$, of which 163 are unique for TAp63 $\alpha$ and eight are in common with $\Delta \mathrm{Np} 63 \alpha$. TAp63 $\alpha$ downregulates 60 genes, 55 of which are unique, whereas five are in common with $\Delta \mathrm{Np} 63 \mathrm{a}$. In contrast, $\Delta \mathrm{Np63} \alpha$ upregulates fewer genes (52), probably by using the second TA domain; ${ }^{16}$ among these, 44 are unique for $\Delta \mathrm{Np} 63 \alpha$ and eight are in common with $\mathrm{TAp} 63 \alpha . \Delta \mathrm{Np} 63 \alpha$ also downregulates 30 genes, 25 of which are unique and the other five are in common with TAp63 $\alpha$ (Figure $8 a$ and b). TAp63 $\alpha$ shows high transcriptional activity and, in particular, drives the expression of proteins specific to the upper layer of the epidermis, such as Ets-1, K1, K10, profilaggrin, involucrin and TG type 3 and 5 . Conversely, $\Delta \mathrm{Np} 63 \alpha$ induced, with a high log ratio, the expression of genes present in the basal layer, such as $\mathrm{K} 14$. The results obtained in gene array analysis were confirmed using real-time PCR (Figure 8c). Accordingly, we searched the promoter region of $\mathrm{K} 14$ gene for potential binding sites. As shown in Figure 9a, three p53-like responsive sites were identified located at $-1813 /-1833$, $-1368 /-1388$ and $-114 /-134$, respectively. This promoter region was cloned in a plasmid upstream of a luciferase reporter gene. We observed that $\Delta \mathrm{Np} 63 \alpha$, but not TAp63 $\alpha$, significantly increased luciferase activity in a dose-dependent manner (Figure 9b). The $\Delta \mathrm{Np} 63 \alpha$-dependent transactivation strictly depends on the p53-like responsive element III (RE III), as deletion of the first and second p53-like consensus sites $(\Delta 1$ and $\Delta 2$ ) has no effect on the ability of $\Delta N p 63 \alpha$ to drive the 


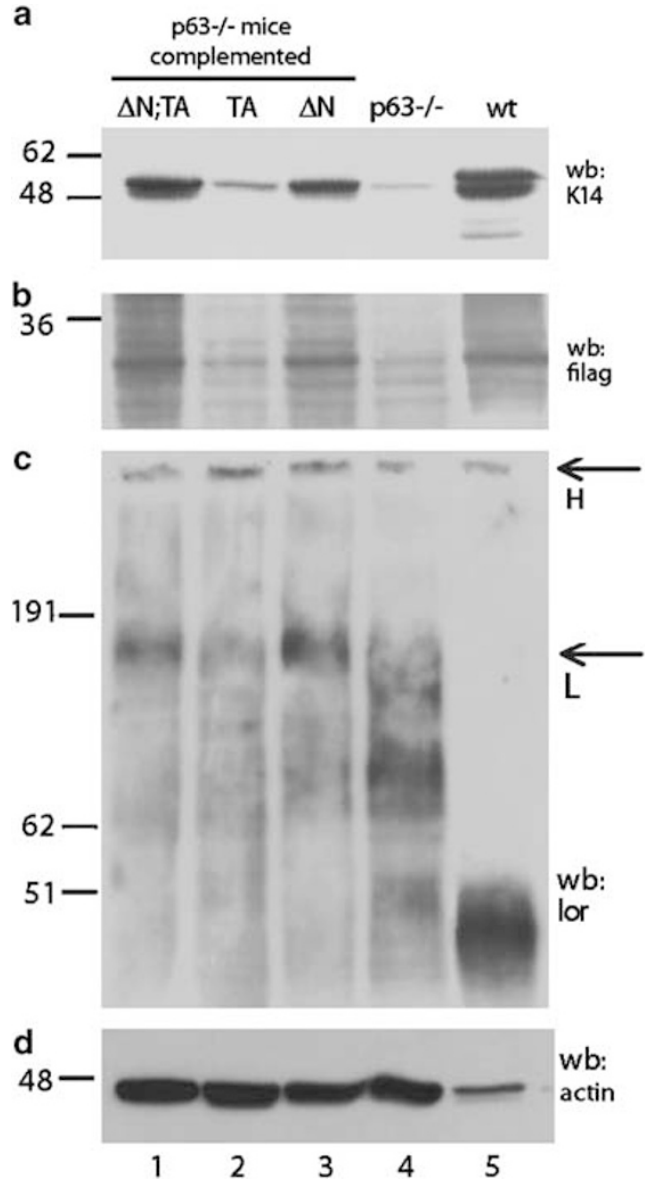

Figure 4 Expression of epidermal differentiation proteins by Western blot in p63-/- mice before and after reintroduction of TAp63 $\alpha$ and/or $\Delta N p 63 \alpha$. (a-d) Expression of cornification proteins in p63-/- mice after the reintroduction of TAp63 $\alpha$ and/or $\Delta$ Np63 $\alpha$. E19.5 embryos were incubated for $24 \mathrm{~h}$ in buffer $(1 \%$ SDS, $20 \mathrm{mM}$ DTT) to solubilise the outermost epidermal layers; proteins were quantified, electrophoresed and blotted. Lanes: $1, \mathrm{p} 63-/-; \Delta \mathrm{N} ; \mathrm{TA} ; 2$ p63-I-;TA ; 3, p63-I-; $\Delta \mathrm{N} ; 4$, p63-I- ; 5, wt. (a) K14 expression. A limited, but definite, K14 expression was already detectable in p63-1- mice. The reintroduction of the $\Delta \mathrm{Np} 63 \alpha$ protein (but not TAp63 $\alpha$ ) was sufficient to significantly increase K14 protein expression. (b) Western blot for filaggrin, already expressed at a low level in p63-/- mice, indicating the ability of at least some keratinocytes to differentiate and express markers of the upper layers. As for K14 (Figure 3a), the reintroduction of the $\Delta$ Np63 $\alpha$ protein (but not TAp63 $\alpha$ ) was sufficient to significantly increase the expression of filaggrin. (c) Western blot for loricrin. Results were similar to filaggrin. Proteins from wt mice showed either monomer, owing to the solubilisation of loricrin from the L-granules, or heavily crosslinked proteins (indicated by L-arrow, low molecular weight polymers; and $\mathrm{H}$-arrow, high molecular weight polymers). All transgenic mice showed mainly intermediate oligomers and no monomer (formation of L-granules is abnormal in these mice). Again, p63-1- mice (and even more mice with reintroduction of the $\Delta N p 63 \alpha$ protein, L-arrow) show the expression of loricrin, with a significant degree of crosslinked polymers, suggesting that at least some TG have been expressed and activated. (d) Loading control, actin

K14 promoter, whereas deletion of the third site $(\Delta 3)$ abolishes $\Delta \mathrm{Np} 63 \alpha$ transcriptional activity (Figure 9b). In order to verify whether p63 was able to directly interact with these consensus sequences, we performed a chromatin immunoprecipitation assay (ChIP) using HaCat cells. Figure $9 \mathrm{c}$ shows the ability of endogenous p63 protein to bind directly the third p53-like binding (RE III) in vivo. By Western blot, we confirmed that $\Delta \mathrm{Np} 63 \alpha$, but not TAp63 $\alpha$, transfected in HEK293
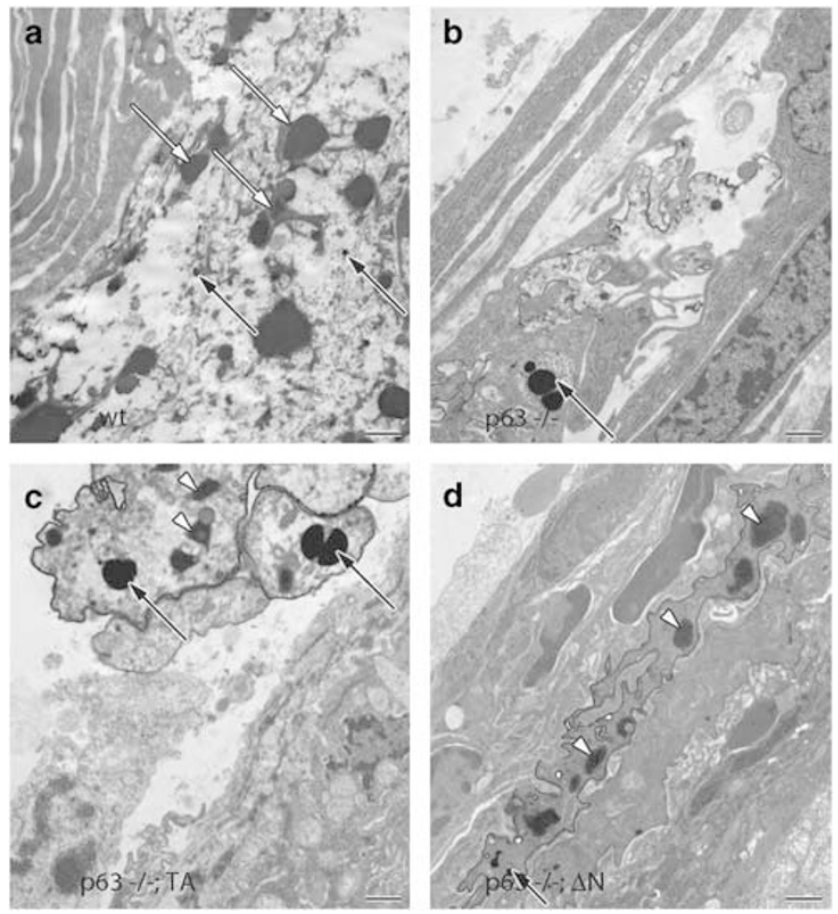

Figure 5 Ultrastructure of epithelial patches following reintroduction of TAp63 $\alpha$ or $\Delta \mathrm{Np} 63 \alpha$ in $\mathrm{p} 63-/-$ mice by genetic complementation showing filaggrin granules (white arrows) and loricrin granules (black arrows). (a) wt mouse; cornified squamous cells (top left) overlie the granular layer where numerous filaggrin granules are associated with keratin fibrils. (b) p63-/- knockout mouse; fibroblast-like cells overlie a cell with localised cornification of the cell envelope and enlarged loricrin granules. (c) p63-l- transgenic mouse with reintroduction of TAp63 $\alpha$; irregular cornified cell envelops contain enlarged loricrin granules and accumulations of a moderately electron-dense material (white arrowheads). (d) p63-1- transgenic mouse with reintroduction of $\Delta \mathrm{Np} 63 \alpha$; flattened cells predominate but cornified cells, with accumulations of a moderately electron-dense material (white arrowheads), are distributed throughout the superficial layers. All bars $=1 \mu \mathrm{m}$

epithelial cells induced the expression of the K14 protein (Figure 9d). Together, these data indicate that $\Delta \mathrm{Np} 63 \alpha$ is able to drive, both in vitro and in vivo, the expression of basal layer markers of the epidermis, such as $\mathrm{K} 14$, whereas TAp63 $\alpha$ is able to drive the expression of proteins of the upper layers of the epidermis.

The effect of the overexpression of p63 isoforms on the expression of $\mathrm{K} 14, \mathrm{~K} 1$ and involucrin was then determined using the previously described $\operatorname{TAp} 63 \alpha$ and $\Delta \mathrm{Np} 63 \alpha$ transgenic mice (Figure 10a and b). K14 is upregulated in $\Delta \mathrm{Np} 63 \alpha$ but not in TAp63 $\alpha$ transgenic mice. In contrast, involucrin and $\mathrm{K} 1$ are the only markers upregulated in TAp $63 \alpha$ transgenic mice. Together, these results are in agreement with the data obtained from the gene array analysis (Figures 8 and 9), and with the effect of the $\Delta \mathrm{Np} 63 \alpha$ in vivo genetic complementation in the p63-knockout mice (Figures 3 and 6). All indicate a role for $\Delta \mathrm{Np63 \alpha}$ in the formation of the basal layer of epidermis.

\section{Discussion}

Several studies have shown both a fundamental role for p63 in epithelial formation, and that p63 is upstream of many genes involved in epithelial development, although no distinct 
a

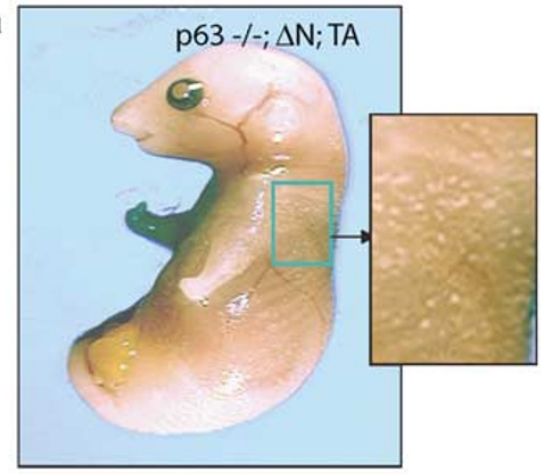

b
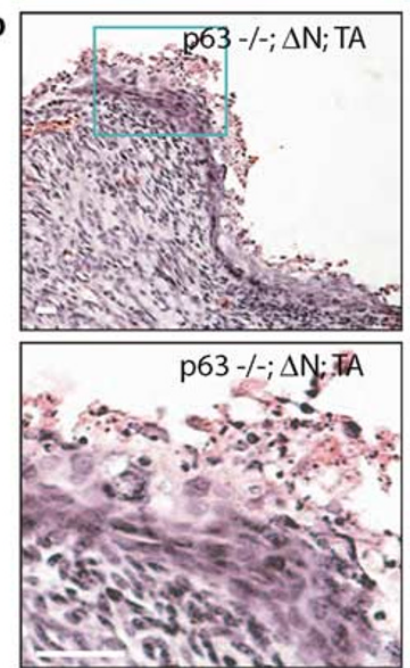

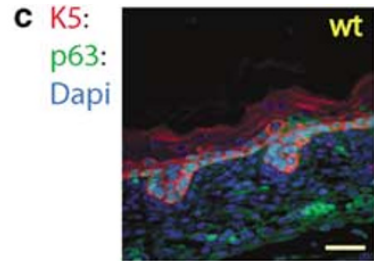

K14:

p63:

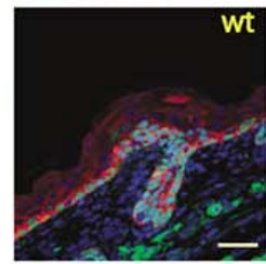

wt
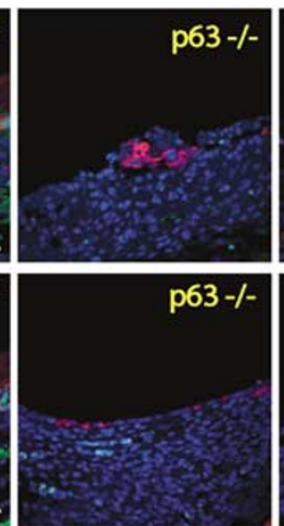

p63-/-

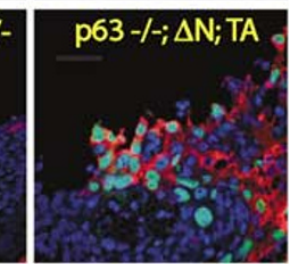

d K1:

p63:

Dapi
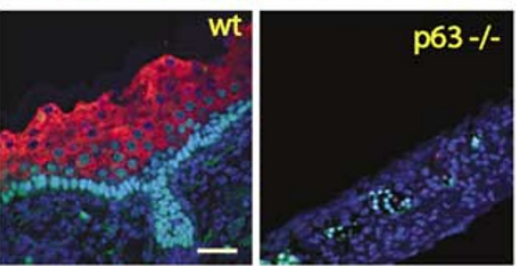

Lor:
p63:
Dapi
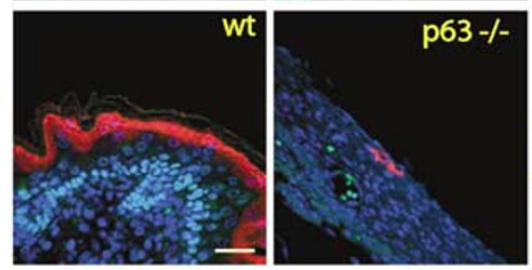

p63-/-; $\Delta \mathrm{N} ; \mathrm{TA}$

p63-/-; $\Delta \mathrm{N} ; \mathrm{TA}$
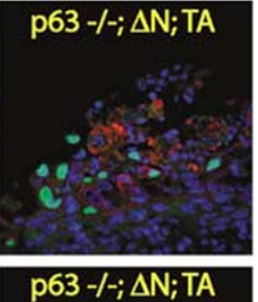

Figure 6 Reintroduction of both TAp63 $\alpha$ and $\Delta \mathrm{Np} 63 \alpha$ into the p63-I- mice. (a) Newborn p63-I-; $\Delta \mathrm{N} ; \mathrm{TA}$ show significant degree of re-epithelialisation. (b) Histology (haematoxylin and eosin (H\&E)). Areas of re-epithelialisation are evident. Bars $=250 \mu \mathrm{m}$ (upper panel) or $50 \mu \mathrm{m}$ (lower panel). (c, d) Confocal immunostaining of skin biopsies of newborn mice. Reintroduction of both $\Delta \mathrm{Np} 63 \alpha$ and TAp63 $\alpha$ into p63-/ - mice allows a greater degree of re-epithelialisation, with expression of differentiated basal (K5, K14) and upper (K1, loricrin) layer markers. White stars indicate autofluorescent blood cells, also visible in unstained slides. $\mathrm{Bar}=50 \mu \mathrm{m}$

function for the isomeric forms encoded by the two promoters $(\Delta \mathrm{Np63}, \mathrm{TAp} 63)$ has previously been established in vivo. Although the epidermal phenotype of the p63 null mice reported by two independent laboratories was similar, their interpretation of the underlying mechanisms was in sharp contrast. Whereas Roop and co-workers ${ }^{10}$ concluded that p63 controls epidermal differentiation, McKeon and coworkers $^{11}$ suggested that epidermal differentiation was normal but that the defect lay in the proliferation potential of the stem cell compartment. In an attempt to resolve this issue, we have generated p63 null mice selectively expressing $\Delta \mathrm{Np} 63 \alpha$ or TAp63 $\alpha$, or both isoforms together. The data are consistent with a role for $\Delta \mathrm{Np} 63 \alpha$ in controlling expansion of progenitor cells in the basal layer, allowing TAp63 $\alpha$ acting synergistically and/or subsequently to control differentiation of upper epidermal layers.

Although reversion of the gross p63 null phenotype was only partial even when both p63 isoforms were introduced, the transgenes were expressed under conditions that may not fully reflect their physiological temporal, spatial and quantitative expression. Moreover, complementation was only performed with the $\mathrm{C}$-terminal $\alpha$ isomers, and an additional role for $\beta$ and $\gamma$ isomers cannot be excluded. Nevertheless, the degree of reconstitution of the gross morphological, histolo- gical and ultrastructural phenotype is greater when $\Delta N p 63$ is selectively reintroduced compared with complementation only with TAp63, although the structural recovery is even more pronounced by complementation with both isoforms. In addition, $\Delta$ Np63 transactivates genes, such as $\mathrm{K} 14$, which are characteristic of the basal layer, whereas transactivation of upper layer genes, such as $\mathrm{K} 1, \mathrm{~K} 10$, filaggrin and loricrin, is mediated by TAp63. However, as expression of these upper epithelial proteins is also increased in mice selectively complemented with $\Delta \mathrm{Np} 63$, other, non-p63 transactivators must also be able to contribute to their expression. ${ }^{17,18}$ The data are also consistent with reports that overexpression of $\Delta \mathrm{Np63}$ in primary murine keratinocytes abrogates calciuminduced growth arrest and blocks expression of maturationspecific proteins, such as K10 and filaggrin. ${ }^{19,20}$

Therefore, within the limitations of our experimental model, our data support a crucial role for p63 in epidermal development (Figure 11). The evidence presented here that $\Delta \mathrm{Np63}$ is more important for maintaining the proliferative potential of the basal layer, whereas TAp63, according to others, ${ }^{21,22}$ contributes to the formation of the upper stratified layers suggests that the two isoforms act in concert, and helps to resolve the previously conflicting interpretations of the role of p63 in the development and maintenance of epithelia. ${ }^{23,24}$ 

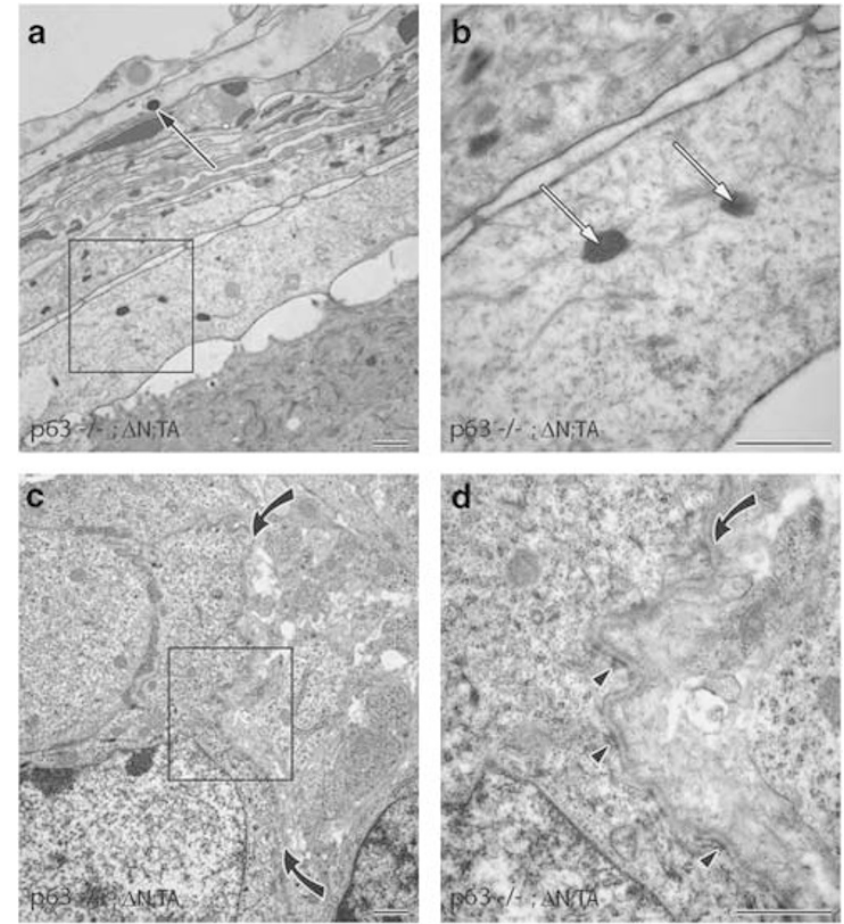

Figure 7 Ultrastructure of epithelial patches following reintroduction of TAp63 $\alpha$ and $\Delta \mathrm{Np} 63 \alpha$ in $\mathrm{p} 63-/-$ mice by genetic complementation showing filaggrin granules (white arrows) and loricrin granules (black arrows). (a-d) TAp63 $\alpha$ and $\Delta N p 63 \alpha$ genetically complemented into $p 63-1-$ mice. (a) Partially cornified squamous cells predominate in the superficial layers and numerous keratin fibrils are present in most cells of the epithelium; the detail is reported as (b). (b) (detail of (a)) Keratin filaments are associated with filaggrin granules in the granular layer. (c) Epithelial cells (left) are separated from the underlying connective tissue by a basement membrane (curved arrows); the detail is reported in (d). (d) (detail of (c)). Numerous indistinct hemidesmosomes are also present at the base of the epithelial cells (black arrowheads). All bars $=1 \mu \mathrm{m}$

\section{Materials and Methods}

\section{Primary keratinocyte, cell cultures and imaging}

Primary keratinocytes were isolated according to Yuspa et al. ${ }^{25}$ from the skin of E19.5 neonates. The skin was floated overnight on trypsin/EDTA at $4^{\circ} \mathrm{C}$ and primary keratinocytes were isolated. Cells were cultured on collagen-coated dishes in medium supplemented with $0.05 \mathrm{mM} \mathrm{Ca}^{2+}$ and $5 \mathrm{ng} / \mathrm{ml}$ epidermal growth factor. TAp63 $\alpha$ - and $\Delta \mathrm{Np} 63 \alpha$-inducible Saos-2 cells were as described by Gressner et al. ${ }^{15}$ Embryos or tissues were fixed in $4 \%$ paraformaldehyde; microwave-assisted antigen retrieval was performed in $0.01 \mathrm{M}$ sodium citrate $(\mathrm{pH} 6)$ for three cycles of $5 \mathrm{~min}$ followed by cooling at $50^{\circ} \mathrm{C}$. Sections were incubated overnight with primary and secondary antibodies for confocal microscopy (Nikon, Tokyo, Japan, C1). Samples for electron microscopy were fixed in formaldehyde/ glutaraldehyde and osmium tetroxide before being embedded in epoxy resin. Sections $(1 \mu \mathrm{m})$ were stained with toluidine blue and examined by light microscopy, to select areas for electron microscopy. Ultrathin sections $(80 \mathrm{~nm})$ were stained with uranyl acetate and lead citrate before examination (Zeiss, Gottingen, Germany, 902A); see below.

\section{Transgenic mice}

A recombination vector containing the $\mathrm{K} 5$ promoter (from Dr. Manfred Blessing, Joannes Gutemberg University, Mainz, Germany) and the
PolyA + signal was used. ${ }^{26}$ Mouse TAp63 $\alpha$ and $\Delta$ Np63 $\alpha$ were tagged at the $\mathrm{N}$-terminus $(\mathrm{HA})$ and cloned into the vector using Clal restriction sites located between the promoter and the polyA + cassette. The fragment containing the expression cassette (K5 promoter/TAp63 $\alpha-\Delta N p 63 \alpha$ l polyA + signal) was released using $K p n l$. The transgenic mice generated are on a pure C57/BL6 background. The p $63+1-$ mice are on a mixed background (129svJ, C57BL/6, see Yang et al. ${ }^{11}$ ).

The genotype was determined from extracted DNA (Qiagen, Valencia, California, USA; see the manufacturer's instructions). PCR was as follows: $95^{\circ} \mathrm{C} \times 3 \mathrm{~min}$ and $30 \mathrm{~s}, 40 \times\left(94^{\circ} \mathrm{C} \times 30 \mathrm{~s}, 50^{\circ} \mathrm{C} \times 35 \mathrm{~s}, 72^{\circ} \mathrm{C} \times 45 \mathrm{~s}\right)$, $72^{\circ} \mathrm{C} \times 5$ min using as forward primer ATA CGA TGT TCC AGA TTA GG and reverse primer TGT TCA TTC CTC CGA CGC AGC. The conditions for PCR screening of p63 $+1-$ mice were as follows: $95^{\circ} \mathrm{C} \times 3 \mathrm{~min}$ and $30 \mathrm{~s}, \quad 40 \times\left(94^{\circ} \mathrm{C} \times 30 \mathrm{~s}, \quad 60^{\circ} \mathrm{C} \times 30 \mathrm{~s}, \quad 72^{\circ} \mathrm{C} \times 1 \mathrm{~min}\right.$ and $\left.30 \mathrm{~s}\right)$, $72^{\circ} \mathrm{C} \times 5$ min using as forward primer TTC TCA GAT GGT ACC GCT $C C$ and reverse primers GGT GCT TTG AGG CCC GGA TC and GAA AGC GAA GGA GCA AAG CTG.

\section{Confocal imaging}

Embryos or tissues were fixed in $4 \%$ paraformaldehyde, embedded in paraffin wax and cut. After wax removal (Histolemon, Carlo Erba, Italy), sections were rehydrated in alcohol/distilled water. Microwave-assisted antigen retrieval was performed in $0.01 \mathrm{M}$ sodium citrate $(\mathrm{pH} 6)$ for three cycles of $5 \mathrm{~min}(300 \mathrm{~W})$ followed by cooling at $50^{\circ} \mathrm{C}$ and a final round of microwaving for $5 \mathrm{~min}$, cooling and a rinse in PBS. Nonspecific antigens were blocked by incubation in $10 \%$ goat serum in PBS for $2 \mathrm{~h}$ at $4{ }^{\circ} \mathrm{C}$. Sections were incubated overnight with the following primary antibodies: monoclonal anti-p63 (Ab4, Neomarkers, Fremont, California, USA; 1/500 dilution), polyclonal anti-MK14 (PRB-155P, Covance; 1/3000 dilution), polyclonal anti-MK5 (PRB-160P, Covance, 1/500 dilution), polyclonal antiMK1 (PRB-165P, Covance; 1/500 dilution), polyclonal anti-involucrin (PRB-142C, Covance; 1/500 dilution), polyclonal anti-filaggrin (PRB-417P, Covance; Princetown, NY, USA; $1 / 500$ dilution), anti-TGase3 (1:200; from R Schmidt, L'Oreal, Paris), polyclonal anti-loricrin (1: 100), ${ }^{10}$ Troma1 (polyclonal anti-K8; 1:10000 dilution; from Developmental Studies Hybridoma Bank, lowa City, IA, USA). Sections were washed three times with PBS and incubated for $1 \mathrm{~h}$ with the secondary antibodies conjugated with FITC or PE. Following two washes in PBS, the tissue sections were incubated for $5 \mathrm{~min}$ with DAPI to reveal the nuclei. The tissue sections were then mounted using the Prolong Antifade kit. Fluorescence was evaluated by confocal microscopy (Nikon, C1 on Eclipse TE200; EZC1 software) fitted with an argon laser ( $488 \mathrm{~nm}$ excitation), a He/Ne laser (542 $\mathrm{nm}$ excitation) and UV excitation at $405 \mathrm{~nm}$ (DAPI staining) from a blue diode.

\section{Electron microscopy}

Samples were fixed in formaldehyde/glutaraldehyde and osmium tetroxide before being embedded in epoxy resin. Sections $(1 \mu \mathrm{m})$ were stained with toluidine blue and examined by light microscopy, to select areas for electron microscopy. Ultrathin sections $(80 \mathrm{~nm})$ were stained with uranyl acetate and lead citrate before examination in a Zeiss $902 \mathrm{~A}$ electron microscope. Several ultrathin sections were treated with $10 \%$ hydrogen peroxide, before staining, to confirm the composition of loricrin granules. ${ }^{27}$

\section{Real-time PCR assay}

RNA was extracted from control and doxycycline-induced Saos-2 TetOnTAp63 and Saos-2 TetOn- $\Delta$ Np63 cells, using the Trizol reagent 
a

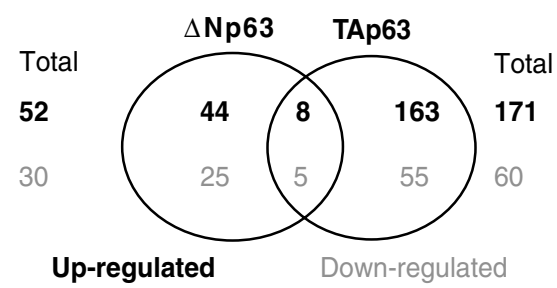

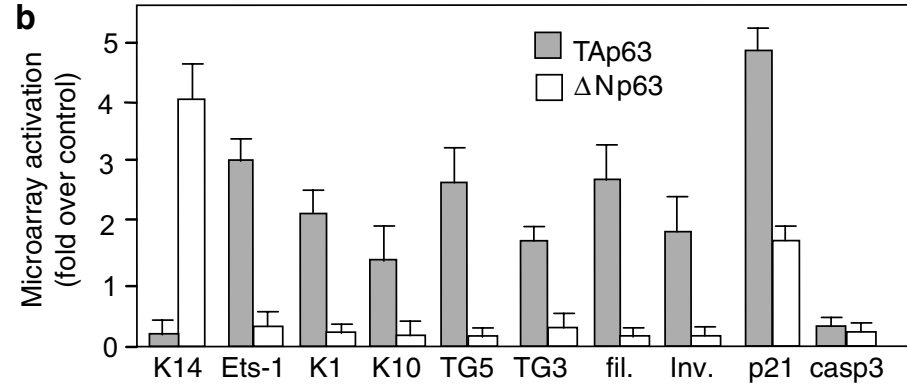

Ets-1
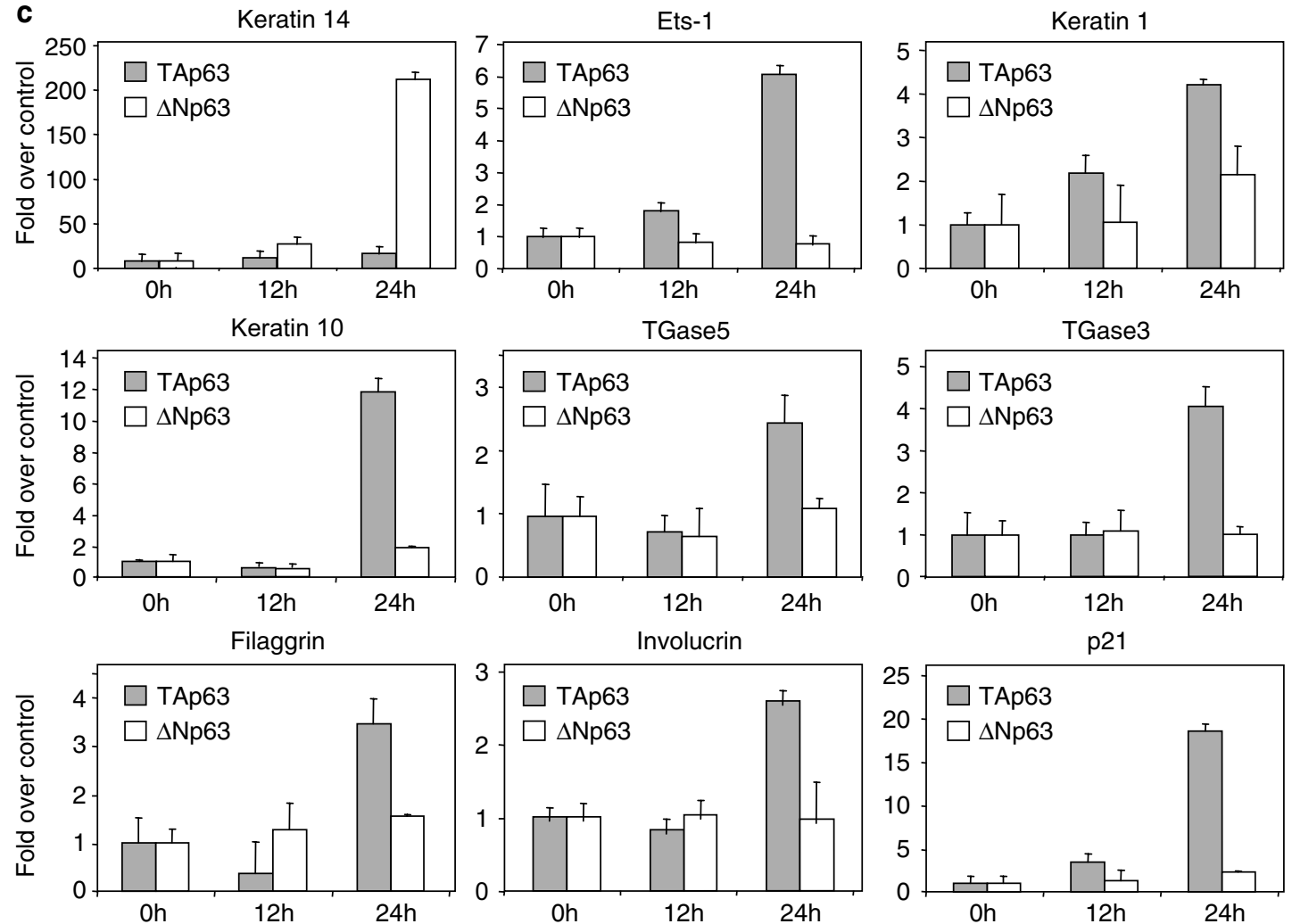

Figure 8 DNA microarray analysis of p63 isoforms. (a) Plot of genes regulated by TAp63 $\alpha$ or $\Delta$ Np63 $\alpha$ isoforms in Tet-inducible Saos-2 cells. The inducible cell lines are described by Gressner et al., ${ }^{15}$ as well as the gene array. (b) Regulation of selected epidermal genes detected in the microarray analysis. The data presented are mean \pm S.D., $n=3$. (c) Validation of target genes, identified in (b), by quantitative real-time PCR. The panels show representative results of two independent inductions. A representative experiment is shown

(Invitrogen, Carlsbad, CA, USA). A $1 \mu \mathrm{g}$ portion of RNA was used for reverse transcription using the InPromll kit (Promega, Madison, WI, USA) and $1 / 5$ of the reaction used for PCR. Real-time PCR was performed using the Platinum SYBR Green qPCR SuperMix UDG with Rox (Invitrogen; cat. no. 11744-500), with an amplification programme as follows: one cycle of $95^{\circ} \mathrm{C}$ for $3 \mathrm{~min}$ and 40 cycles of $94^{\circ} \mathrm{C}$ for $15 \mathrm{~s}$ and $59^{\circ} \mathrm{C}$ for $50 \mathrm{~s}$. The reaction was followed by a melting curve protocol according to the specification of the ABI 7000 instrument (Applied Biosystem, Foster City, CA, USA). Amplicon sizes were between 200 and $230 \mathrm{bp}$. The primers used were as follows: TGM5 (+ AGC CTG CAT ACA CCT TCC CTT C; -AAC GCT GTG TCC TGC CAG AAT G), TGM3 (+ TAT CAG CAT CTC CAG TCC TGC C; -GCC AAT TCG GTT TGT GCT TCC), K1 (+ TCA TCA ACT ACC AGC GCA GG; -ACC ATA ACC ACC ACC AAA GC), involucrin ( + CAG GTC CAA GAC ATT CAA CC; -CAA GTT CAC AGA TGA GAC GG), filaggrin ( + CAA TCA GGC ACT CAT CAC AC; - ACT GTT AGT GAC CTG ACT ACC), IKK- $\alpha$ ( + GAA AAG GCC ATC CAC TAT
GC; -TCA CCA TCT CTG TGC TGT C), p21 (+ TGA GCG ATG GAA CTT CGA C; -ACA AGA CAG TGA CAG GTC C), ETS-1 (+ TCA AGC CGA CTC TCA CCA TC; -CGA ACA TGG GTT TCT GTC CAC, hETS1R), $\beta$-actin ( + AAA GAC CTG TAC GCC AAC A; -CGG AGT ACT TGC GCT CAG). $\beta$-Actin was used as a housekeeping gene for quantity normalisation. Relative quantisation of gene expression was performed according to the method described in $\mathrm{ABI}$ User Bulletin \# 2 (updated October 2001).

\section{Western blots and microarray}

Subconfluent HEK293 cells in $10 \mathrm{~cm}$ dishes were transfected with $15 \mu \mathrm{g}$ of total DNA using $30 \mu \mathrm{l}$ of lipofectamine 2000 reagent (Invitrogen). The amounts of HA-tagged TAp63 $\alpha$ and $\Delta N p 63 \alpha$ were normalised for protein level by transfecting $5 \mu \mathrm{g}$ of TAp63 $\alpha$ vector and $15 \mu \mathrm{g}$ of $\Delta \mathrm{Np} 63 \alpha$ vector. Cells were harvested $24 \mathrm{~h}$ after transfection and lysed in RIPA buffer with 
a

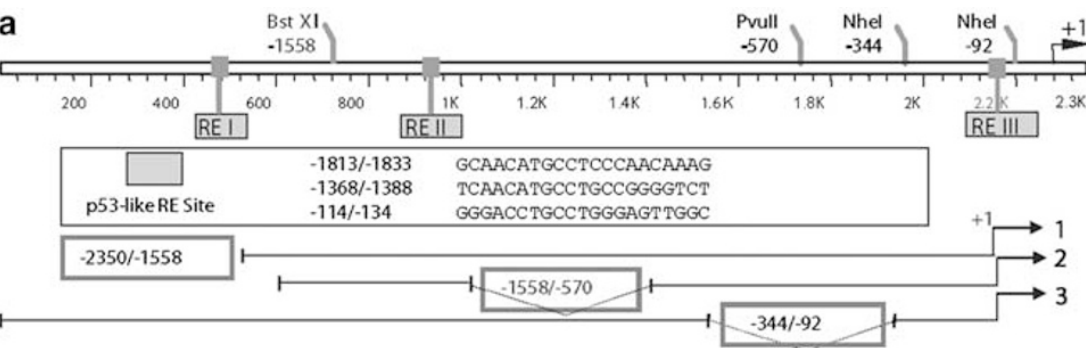

b

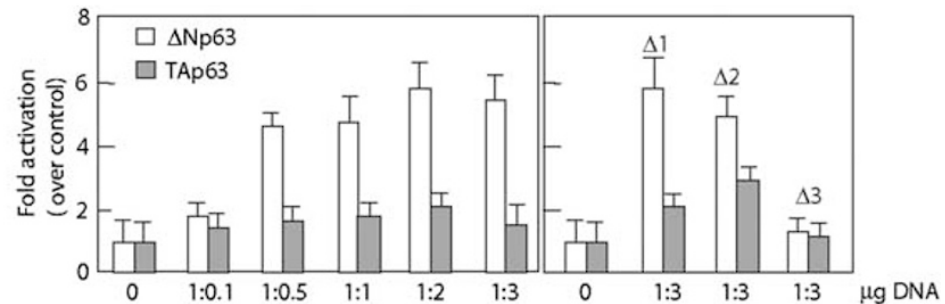

C

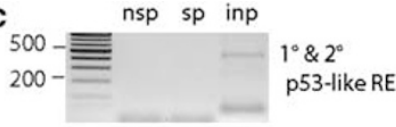

nsp sp inp

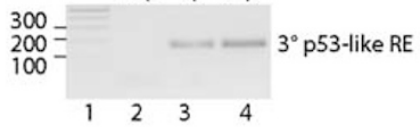

d

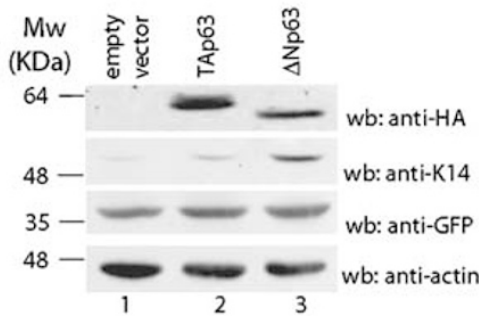

Figure $9 \Delta \mathrm{Np63 \alpha}$ directly transactivates the K14 promoter. (a) Map of the human K14 promoter region. The grey boxes represent p53-like responsive elements; corresponding bps, sequences and restriction enzymes used to generate deleted constructs are indicated $(\Delta 1-3)$. (b) $\Delta$ Np63 $\alpha$ transactivates the K14 promoter in a dose-dependent manner, as indicated in the luc assay. Deletion of the third p53-like RE completely abrogates transactivation by $\Delta$ Np63 $\alpha$. The luc assay (shown) was performed in Saos-2 cells, and similar results were also obtained in HEK293 cells (not shown). Three independent experiments were performed, and a representative result is shown (mean \pm S.D., $n=3$ ). (c) ChIP of p63 protein on the K14 promoter using oligonucleotides for the p53-like binding sites 1-2 or 3. The ChIP was performed using nuclear extracts from HaCat cells (lane 1: marker; lane 2: non-specific antibody (nsp); lane 3: specific antibody anti-p63 (sp); lane 4: input. A representative result of two independent experiments is shown. (d) Western blot of K14 induced by $\Delta$ Np63 $\alpha$ upon transient transfection in HEK293 cells. Cells were co-transfected with a plasmid containing GFP in order to monitor transfection efficiency. Western blot of actin was used as loading control. A representative result of two independent experiments is shown
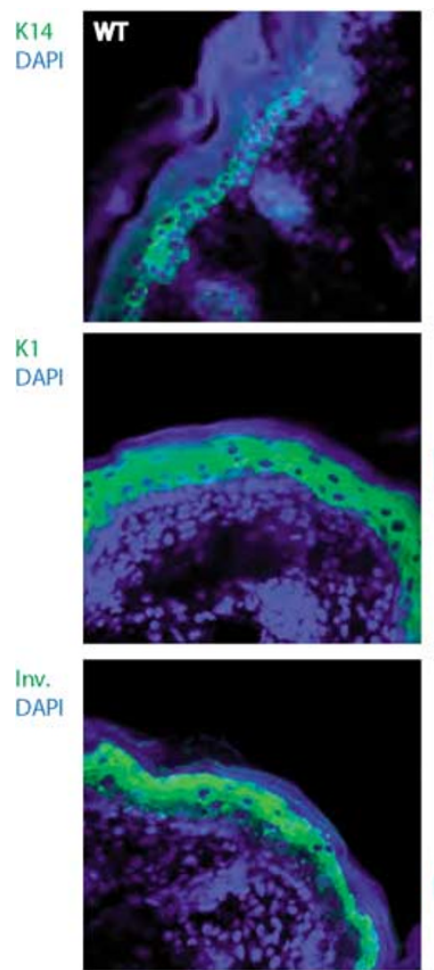
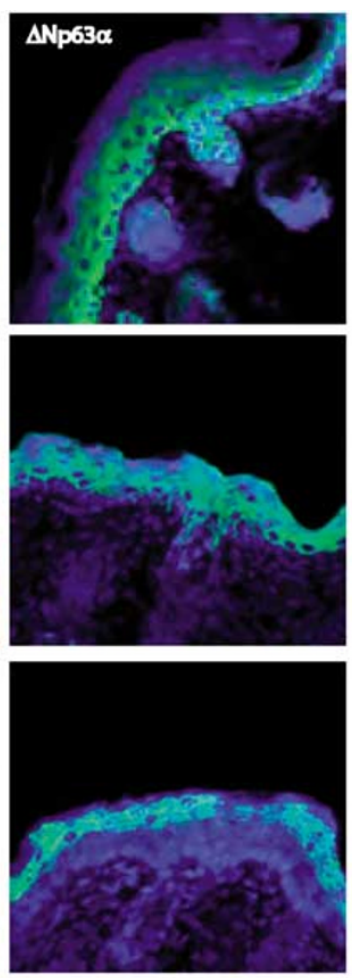
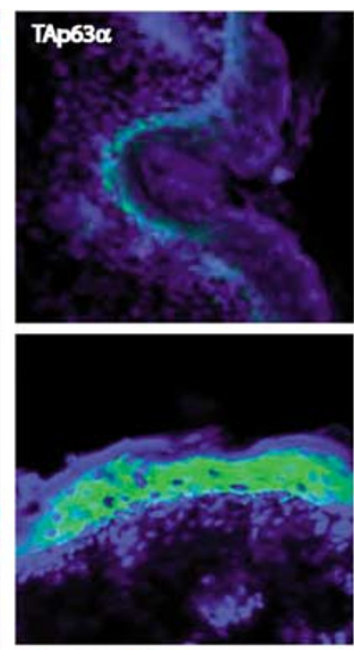

$\Delta \mathrm{Np} 63 \alpha$

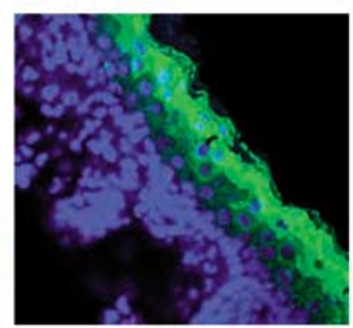

TAp63 $\alpha$
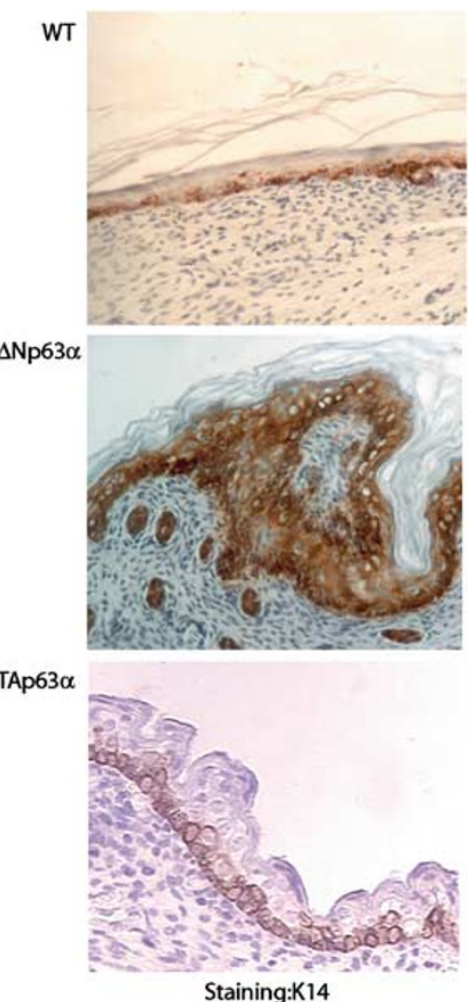

Figure 10 In vivo validation, in transgenic mice overexpressing either TAp63 $\alpha$ or $\Delta$ Np63 $\alpha$ isoforms, of K14 as a target of $\Delta$ Np63 $\alpha$, identified in Figures 8 and 9 . (a, b) Expression of epidermal proteins in transgenic mice overexpressing TAp63 $\alpha$ or $\Delta$ Np63 $\alpha$ isoforms under the control of the K5 promoter; see also Figure 1. (a) Confocal images of K14, K1 and involucrin in the epidermis of both newborn wt and transgenic mice. Bar $=50 \mu \mathrm{m}$. (b) Immunohistochemistry of $\mathrm{K} 14$ staining in different wt and transgenic newborn mice. Bar $=100 \mu \mathrm{m}$ 


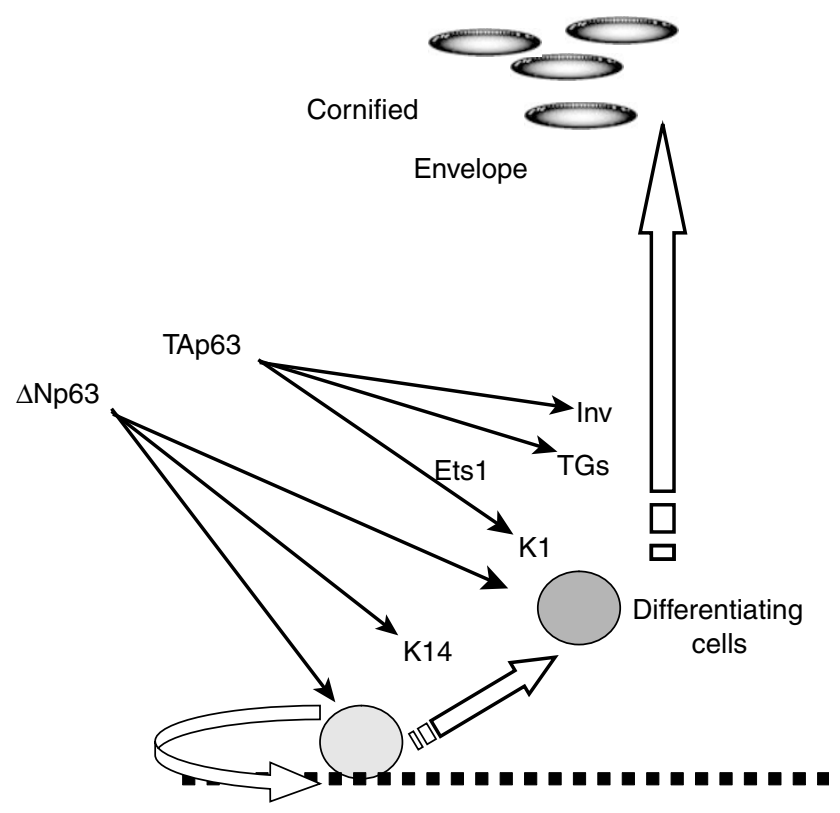

stem cell

Figure 11 Proposed scheme of action of the p63 isoforms deducted from the experiment reported. Within the limit of our experimental model, the data reported indicate that (i) p63-1- epidermis shows very limited and only partially differentiated epithelial areas, indicating that p63 is not strictly required for the expression of epithelial differentiation proteins (as loricrin, involucrin and K1/K10 are expressed in p63 null animals); our data are consistent with p63-/- mice retaining a limited expansion of the proliferative compartment (patchy epidermis), which in places is able to differentiate (expression of loricrin, involucrin, $\mathrm{K} 1 / \mathrm{K} 10$ ); (ii) $\Delta \mathrm{Np} 63 \alpha$ significantly increases the number of epidermal basal cells, consequently allowing a greater degree of differentiation, and therefore $\Delta \mathrm{Np} 63$ would appear to be the isoform responsible for the proliferation potential function (expansion of the basal layer); (iii) both TAp63 $\alpha$ and $\Delta N p 63 \alpha$ are required for epidermal development, as single genetic complementation does not fully revert the null phenotype; and therefore, (iv) TAp63 $\alpha$ and $\Delta N p 63 \alpha$ have different, complementary, synergistic functions necessary for the complete formation of the epidermis, where TAp63 facilitates the expression of differentiation markers (but is not strictly required, as p63-1- also express these proteins to a limited extent; see point (i)); (v) p63 exerts its effects at least in part by acting directly upstream of K14 (directly transactivated by $\Delta \mathrm{Np} 63 \alpha$ ) and Ets-1, K1, TG and involucrin (inv) (directly transactivated by TAp63 $\alpha$ )

protease inhibitors (Sigma, St. Louis, MI, USA) and $1 \mathrm{mM}$ DTT (Sigma). Primary mouse keratinocytes were lysed in a buffer containing $100 \mathrm{mM}$ $\mathrm{NaCl}, 1 \%$ Triton X-100, 0.5\% NP-40, 0.5\% sodium deoxycholate, $1 \mathrm{mM}$ EDTA and $1 \mathrm{mM}$ DTT. To extract proteins from E19.5 embryonic skin, embryos were incubated at room temperature (RT) for $24 \mathrm{~h}$ in $100 \mathrm{mM}$ Tris- $\mathrm{HCl} \mathrm{pH} 8.5,1 \%$ SDS, $20 \mathrm{mM}$ DTT and $5 \mathrm{mM}$ EDTA; $50 \mu \mathrm{g}$ of extracted proteins was separated on SDS-PAGE and transferred onto polyvinylidendifluoride membranes; blots were kept in blocking solution for $2 \mathrm{~h}$. Blots were incubated for $2 \mathrm{~h}$ with shaking at $\mathrm{RT}$ with the following primary antibodies: monoclonal anti-p63 (1:200 dilution), polyclonal antiHA (Y-11, Santa Cruz, CA, USA, 1:100 dilution), polyclonal anti-K14; polyclonal, anti-loricrin and anti-filaggrin (1:300 dilution). Normalisation was achieved with a polyclonal anti-tubulin $(\mathrm{H}-235$, Santa Cruz, $1: 1000$ dilution) or with a goat anti-actin antibody (C-11, Santa Cruz, 1:1000 dilution). After three washes in PBS-tween 20 (0.05\%), HRP-conjugated secondary antibodies (Bio-Rad, goat anti-mouse, 170-5047 and goat antirabbit, 170-5046; and Santa Cruz, bovine anti-goat, sc-2384) were added ( $1: 10000-20000$ dilution in blocking solution). Proteins were detected using the ECL method.
TAp63 $\alpha / \Delta$ Np63 $\alpha$ dox-inducible Saos-2 cells were as described by Gressner et al. ${ }^{15}$ cRNAs were hybridised to the Genechip HuGene FL array (Affymetrix, Santa Clara, CA, USA) that contains probes for about 11000 mRNA species. Scanned output files were inspected for hybridisation artefacts and further analysed using Genechip 3.3 software (Affymetrix). Ratios were obtained by dividing the average difference of TAp63 $\alpha$ and $\Delta \mathrm{Np63}$ for each time point with those of the $0 \mathrm{~h}$ time point.

\section{Chromatin immunoprecipitation and luciferase assay}

Cells $\left(1.5 \times 10^{6}\right)$ were crosslinked for $5 \mathrm{~min}$, with $1 \%$ formaldehyde, $5 \mathrm{mM}$ Hepes-KOH pH 8.0, $0.1 \mathrm{mM}$ EDTA and $10 \mathrm{mM} \mathrm{NaCl}$. Crosslinking was stopped by incubating cells with $0.125 \mathrm{M}$ glycine for $5 \mathrm{~min}$ at RT. After washing with ice-cold PBS, cells were harvested in lysis buffer $(50 \mathrm{mM}$ Hepes-KOH pH 8.0, $1 \mathrm{mM}$ EDTA, $140 \mathrm{mM} \mathrm{NaCl}, 25 \%$ glycerol, 0.5\% NP$40,0.25 \%$ Triton X-100) plus protease inhibitors. The nuclei were collected by centrifugation and resuspended in wash buffer $(10 \mathrm{mM}$ Tris- $\mathrm{HCl} \mathrm{pH} 8.0$, $1 \mathrm{mM}$ EDTA, $200 \mathrm{mM} \mathrm{NaCl}$ ) plus protease inhibitors. After centrifugation, the nuclei were resuspended in $1.8 \mathrm{ml}$ ChIP Dilution Buffer $(0.01 \%$ SDS, $1.1 \%$ Triton $\mathrm{X}-100,1.2 \mathrm{mM}$ EDTA, $0.0167 \mathrm{M}$ Tris- $\mathrm{HCl}, 0.167 \mathrm{M} \mathrm{NaCl}$ ) plus $200 \mu$ l SDS lysis buffer (1\% SDS, 10 mM EDTA, 50 mM Tris-HCl pH 8.1). Cell lysates were sonicated in order to obtain chromatin fragments of $\sim 700$ bp. After centrifugation at 13000 r.p.m. for 20 min to remove any cell debris, $100 \mu \mathrm{g}$ of total proteins was precleared with $100 \mu \mathrm{l}$ of protein Aagarose/salmon sperm DNA (Upstate, Charlottesville, VA, USA) and $2 \mu \mathrm{g}$ of mouse $\lg _{1} \kappa\left(B D\right.$, Franklin Lakes, NJ, USA) for $2 \mathrm{~h}$ at $4^{\circ} \mathrm{C}$. Then, the precleared extracts were incubated with $2 \mu \mathrm{g}$ monoclonal anti-HA (16B12, Covance) or monoclonal anti-p63 (Ab4, Neomarkers) overnight at $4^{\circ} \mathrm{C}$, followed by incubation with protein A-agarose/salmon sperm DNA $(60 \mu \mathrm{l})$ for $1 \mathrm{~h} 30 \mathrm{~min}$ at $4^{\circ} \mathrm{C}$. The negative control was incubated with $2 \mu \mathrm{g}$ mouse anti-K5 (Santa Cruz). The immune complexes were washed twice with low-salt wash buffer $(0.1 \%$ SDS, $1 \%$ Triton X-100, 2 mM EDTA, $20 \mathrm{mM}$ Tris- $\mathrm{HCl}, 0.15 \mathrm{M} \mathrm{NaCl})$, five times with high-salt wash buffer $(0.1 \% \mathrm{SDS}$, $1 \%$ Triton X-100, $2 \mathrm{mM}$ EDTA, $20 \mathrm{mM}$ Tris- $\mathrm{HCl}, 0.5 \mathrm{M} \mathrm{NaCl}$ ), once with $\mathrm{LiCl}$ salt wash buffer (1 mM EDTA, $10 \mathrm{mM}$ Tris- $\mathrm{HCl}, 0.25 \mathrm{M} \mathrm{LiCl}, 1 \% \mathrm{NP}$ $40,1 \%$ deoxycholate) and twice with TE buffer. The precipitates were extracted twice using $250 \mu \mathrm{l}$ of IP elution buffer (1\% SDS, $0.1 \mathrm{M} \mathrm{NaHCO3).}$ The total eluates $(500 \mu \mathrm{l})$ were pooled by adding $20 \mu \mathrm{l}$ of $5 \mathrm{M} \mathrm{NaCl}$ and incubated at $65^{\circ} \mathrm{C}$ for at least $6 \mathrm{~h}$ to reverse the formaldehyde crosslinking. DNA fragments were purified by phenol-chloroform extraction and ethanol precipitation, and dissolved in $30 \mu \mathrm{l}$ of sterile water.

DNA samples were then analysed with 38 cycles of PCR to amplify K14 promoter sequences $\left(94^{\circ} \mathrm{C}\right.$ for $30 \mathrm{~s}, 58^{\circ} \mathrm{C}$ for $40 \mathrm{~s}, 72^{\circ} \mathrm{C}$ for $\left.40 \mathrm{~s}\right)$. We used a primer pair amplifying the first and second p53 responsive element in the K14 promoter (forward $5^{\prime}$-CCTCTTCGGCCGGTGGAC-3' and reverse $5^{\prime}$-CCGTTTTCGACCCTGAGAG-3') and two other primers amplifying the third p53 responsive element (forward 5'-CCTCTTCGGCC GGTGGAC-3' and reverse 5'-CCGTTTTCGACCCTGAGAG-3').

Subconfluent HEK293 cells in 12-well dishes were transfected with Effectene-Liposomal Transfection Reagent (Qiagen, Hilden, Germany) at a 1:3 ratio between the reporter plasmid (containing the firefly luciferase gene under the control of K14 promoter) and the expression vectors encoding for TAp63 $\alpha$ and $\Delta$ Np63 $\alpha$. When needed, the pcDNA empty vector (Invitrogen) was added to reach the total amount of DNA (400 ng) used in each transfection. In all cases, $10 \mathrm{ng}$ of Renilla Luciferase Vector (pRL-CMV; Promega, Madison, WI, USA) was co-transfected, as a control of transfection efficiency. At $24 \mathrm{~h}$ after transfection, luciferase activities of cellular extracts were measured, by using a Dual Luciferase Reporter 
Assay System (Promega, Madison, WI, USA); light emission was measured over $10 \mathrm{~s}$ using an OPTOCOMP I luminometer. Efficiency of transfection was normalised using Renilla luciferase activity.

\section{Acknowledgements}

We thank Dr. F McKeon for providing us with the p63-1- mice, Dr. C Tiveron for crucial help and advice in the generation of the transgenic mice, and Mr. A Colangeli and J McWilliam for ultramicrotomy. This work was supported by grants from Telethon to EC; AIRC to VDL; and EU, AIRC, Telethon, FIRB, MIUR, MinSan, TelethonGGP04110 and MRC to GM.

\section{Note added in proof}

After this paper was accepted, Laurikkala et al. (Laurikkala J, Mikkola ML, James M, Tummers M, Mills AA and Thesleff I (2006) P63 regulates multiple signaling pathways required for ectodermal organogenesis and differentiation. Development 133: in press. Published online on March 8, 2006. doi: $10.1242 /$ dev.0235) demonstrated that $\Delta N p 63$ is the main isoform expressed at all embryonic stages during epidermal, tooth and hair development, accounting for $100 \%$ of all p63 expressed up to E9 and $99 \%$ at E13. TAp63 expression starts at E13, and only accounts for $1 \%$ of total p63 protein expressed at this time. Thus, expression of the $\Delta \mathrm{Np} 63$ isoform is predominant over that of TAp63, at a time before any epidermal stratification occurs. These results obtained by Laurikkala et al. are fully in agreement with our studies, using a completely different experimental approach, and confirm that the $\Delta \mathrm{Np} 63$ isoform is crucial for the formation of the epidermis, whereas TAp63 contributes to the control of epithelial differentiation by acting synergistically and/or subsequently to $\Delta \mathrm{Np} 63$.

Moreover, Laurikkala et al. also demonstrated that Bmp 7, Fgfr2b, Jag1 and Notch1 transcripts are coexpressed with $\triangle \mathrm{Np} 63$ and are absent in p63-/-mice. Additional support for this complex pathway of regulations also comes from a further independent paper in press (Nguyen BC, Lefort K, Mandinova A, Antonini D, Devgan V, Della Gatta G, Koster MI, Zhang Z, Wang J, Tommasi di Vignano A, Kitajewski J, Chiorino G, Roop DR, Missero $C$ and Dotto GP (2006). Cross- regulation between Notch and p63 in keratinocyte commitment to differentiation. Genes Dev. in press. doi:10.1101/gad1406006).

\section{References}

1. Candi E, Schmidt R and Melino G (2005) The cornified envelope: a model of cell death in the skin. Nat. Rev. Mol. Cell Biol. 6: 328-340.

2. Fuchs $E$ and Watt FM (2003) Cell differentiation. Focus on epithelia. Curr. Opin. Cell Biol. 15: 738-739.

3. Owens DM and Watt FM (2003) Contribution of stem cells and differentiated cells to epidermal tumours. Nat. Rev. Cancer 3: 444-451.

4. Yang A, Kaghad M, Wang Y, Gillett E, Fleming MD, Dotsch V, Andrews NC, Caput D and McKeon F (1998) p63, a p53 homolog at 3q27-29, encodes multiple products with transactivating, death-inducing, and dominant-negative activities. Mol. Cell 2: 305-316.

5. Melino G, De Laurenzi V and Vousden KH (2002) p73: friend or foe in tumorigenesis. Nat. Rev. Cancer 2: 605-615.

6. Melino G, Lu X, Gasco M, Crook T and Knight RA (2003) Functional regulation of p73 and p63: development and cancer. Trends Biochem. Sci. 28: 663-670.

7. Yang A, Kaghad M, Caput D and McKeon F (2002) On the shoulders of giants: p63, p73 and the rise of p53. Trends Genet. 18: 90-95.

8. Yang A and McKeon F (2000) P63 and P73: P53 mimics, menaces and more. Nat. Rev. Mol. Cell Biol. 1: 199-207.
9. Celli J, Duijf P, Hamel BC, Bamshad M, Kramer B, Smits AP, Newbury-Ecob R, Hennekam RC, Van Buggenhout G, van Haeringen A, Woods CG, van Essen AJ, de Waal R, Vriend G, Haber DA, Yang A, McKeon F, Brunner HG and van Bokhoven $\mathrm{H}$ (1999) Heterozygous germline mutations in the p53 homolog p63 are the cause of EEC syndrome. Cell 99: 143-153.

10. Mills AA, Zheng B, Wang XJ, Vogel H, Roop DR and Bradley A (1999) p63 is a p53 homologue required for limb and epidermal morphogenesis. Nature 398: 708-713.

11. Yang A, Schweitzer R, Sun D, Kaghad M, Walker N, Bronson RT, Tabin C, Sharpe A, Caput D, Crum C and McKeon F (1999) p63 is essential for regenerative proliferation in limb, craniofacial and epithelial development. Nature 398: 714-718.

12. Bernassola F, Oberst A, Melino G and Pandolfi PP (2005) The promyelocytic leukaemia protein tumour suppressor functions as a transcriptional regulator of p63. Oncogene 24: 6982-6986.

13. Keyes WM, Wu Y, Vogel H, Guo X, Lowe SW and Mills AA (2005) p63 deficiency activates a program of cellular senescence and leads to accelerated aging. Genes Dev. 19: 1986-1999.

14. Lechler T and Fuchs $E$ (2005) Asymmetric cell divisions promote stratification and differentiation of mammalian skin. Nature 437: 275-280.

15. Gressner O, Schilling T, Lorenz K, Schulze Schleithoff E, Koch A, SchulzeBergkamen H, Maria Lena A, Candi E, Terrinoni A, Valeria Catani M, Oren M, Melino G, Krammer PH, Stremmel W and Muller M (2005) TAp63alpha induces apoptosis by activating signaling via death receptors and mitochondria. EMBO J. 24: 2458-2471.

16. Ghioni P, Bolognese F, Duijf PH, Van Bokhoven H, Mantovani R and Guerrini L (2002) Complex transcriptional effects of p63 isoforms: identification of novel activation and repression domains. Mol. Cell. Biol. 22: 8659-8668.

17. De Laurenzi V, Rossi A, Terrinoni A, Barcaroli D, Levrero M, Costanzo A, Knight RA, Guerrieri P and Melino G (2000) p63 and p73 transactivate differentiation gene promoters in human keratinocytes. Biochem. Biophys. Res. Commun. 273: 342-346.

18. Lapi E, lovino A, Fontemaggi G, Soliera AR, lacovelli S, Sacchi A, Rechavi G, Givol D, Blandino G and Strano S (2006) S100A2 gene is a direct transcriptional target of p53 homologues during keratinocyte differentiation. Oncogene [Epub ahead of print].

19. King KE, Ponnamperuma RM, Yamashita T, Tokino T, Lee LA, Young MF and Weinberg WC (2003) deltaNp63alpha functions as both a positive and a negative transcriptional regulator and blocks in vitro differentiation of murine keratinocytes. Oncogene 22: 3635-3644.

20. King KE, Ponnamperuma RM, Gerdes MJ, Tokino T, Yamashita T, Baker CC and Weinberg WC (2006) Unique domain functions of p63 isotypes that differentially regulate distinct aspects of epidermal homeostasis. Carcinogenesis 27: 53-63.

21. Ihrie RA, Marques MR, Nguyen BT, Horner JS, Papazoglu C, Bronson RT, Mills AA and Attardi LD (2005) Perp is a p63-regulated gene essential for epithelial integrity. Cell 120: 843-856.

22. Koster MI, Kim S, Mills AA, DeMayo FJ and Roop DR (2004) p63 is the molecular switch for initiation of an epithelial stratification program. Genes Dev. 18: 126-131.

23. McKeon $F(2004)$ p63 and the epithelial stem cell: more than status quo? Genes Dev. 18: 465-469.

24. Nicotera $P$ and Melino $G$ (2005) Neurodevelopment on route p63. Neuron 48: 707-709.

25. Yuspa SH, Kilkenny AE, Steinert PM and Roop DR (1989) Expression of murine epidermal differentiation markers is tightly regulated by restricted extracellular calcium concentrations in vitro. J. Cell Biol. 109: 1207-1217.

26. Breuhahn K, Mann A, Muller G, Wilhelmi A, Schirmacher P, Enk A and Blessing M (2000) Epidermal overexpression of granulocyte-macrophage colonystimulating factor induces both keratinocyte proliferation and apoptosis. Cell Growth Differ. 11: 111-121.

27. Jessen H (1970) Two types of keratohyalin granules. J. Ultrastruct. Res. 33: 95-115.

28. Jacobs WB, Govoni G, Ho D, Atwal JK, Barnabe-Heider F, Keyes WM, Mills AA, Miller FD and Kaplan DR (2005) P63 is an essential proapoptotic protein during neural development. Neuron 48: 743-756. 